\title{
Comunicação pública, esfera pública e cotidiano profissional: solo de alfabetização política
}

Public communication, public sphere and professional daily routine: grounds for political literacy

Comunicación pública, esfera pública y cotidiano profesional: terreno de alfabetización política

Regina Célia Escudero

- Doutora em Ciências da Comunicação pela Escola de Comunicações e Artes da Universidade de São Paulo (ECA-USP), com estágio na Universidade Nova de Lisboa (UNL)

- Mestre em Comunicação Social pela Universidade Metodista de São Paulo (Umesp)

- Graduada em Relações Públicas pela Universidade Estadual de Londrina (UEL)

- Professora adjunta da UEL

- Artigos publicados nas áreas de comunicação pública e comunitária

- E-mail: reginac.escudero@gmail.com 


\section{Resumo}

0 artigo aborda aspectos que frequentam a esfera pública da atualidade e que tornam urgente seu debate entre profissionais da comunicação. Questões como os "novos públicos" da esfera pública que configuram os "novos movimentos sociais" surpreendem a todos com sua irreverência e complexidade de informação. Para além desta análise performática da nova esfera pública, nos propomos refletir sobre o paradigma ético-político que orienta as relações públicas e apresentar uma nova proposta paradigmática, fundamentada na ética da discussão e na comunicação pública.

\section{PALAVRAS-CHAVE: RELAÇÕES PÚBLICAS • ESFERA PÚBLICA • ÉTICA DA DISCUSSÃO • PÚBLICO/PRIVADO • COMUNICAÇÃO PÚBLICA.}

\section{Abstract}

The article addresses aspects verified in the current public sphere and urgently calling for being discussed among professionals of communication sciences. Issues such as the "new audiences" of the public sphere that compose the "new social movements" surprise everyone with their irreverence and information complexity. Besides this performative analysis of the new public sphere, we propose to reflect on the ethical-political paradigm that guides public relations, and also to present a new paradigmatic proposal, grounded on the ethics of discussion and on public communication.

\section{KEYWORDS: PUBLIC RELATIONS • PUBLIC SPHERE・DISCUSSION ETHICS • PUBLIC/PRIVATE・PUBLIC COMMUNICATION.}

\section{Resumen}

El artículo aborda aspectos que frecuentan elámbito público de la actualidad y que tornan urgente su debate entre profesionales de la comunicación. Cuestiones como los "nuevos públicos" del ámbito público que configuran los "nuevos movimientos sociales" sorprenden a todos con su irreverencia y complejidad de información. Además de este análisis performático del nuevo ámbito público, nosotros proponemos reflexionar sobre el paradigma ético-político que orienta las relaciones públicas y también presentar una nueva propuesta paradigmática, fundamentada en la ética de la discusión y comunicación pública. 
ste artigo visa ampliar reflexões sobre o cotidiano de profissionais preocupados em transformar conceitos conservadores sobre as humanidades em paradigmas de ação crítica, como, também, valores e princípios éticos em objetivos e metas operacionais transformadores.

No campo de relações públicas, o dilema entre o ser e o fazer profissional' aponta grande abismo, pois sua emergência, no período de 1930, ficou atrelada aos interesses privados, focando demandas específicas de grupos dominantes da sociedade estadunidense. Afirmamos que o início da profissão marcou grande distorção em seu sentido ético e social (Escudero, 2015, p. 178). É necessário reestabelecer a unidade teoria-prática numa dimensão transformadora, antes alinhada com a esfera privada em lugar da esfera pública. Nessa reconstrução paradigmática é primordial o eixo éticopolítico orientador do profissional de relações públicas.

Sustentados nessas premissas e inspirados em Jürgen Habermas, abordamos "mundo da vida" buscando entender 0 cotidiano, os modos de apreendê-lo e de nele atuar, num esforço de superação da razão comunicativa instrumental, dandolhe caráter crítico-participativo, através da "ética da discussão". Compõem nosso texto conceitos de comunicação pública, esfera pública e dos "novos movimentos sociais", analisando-os à luz da nossa prática profissional na cidade de Londrina (PR).

\section{ÉTICA DA DISCUSSÃO: UM PROJETO ÉTICO-PROFISSIONAL}

A opção metodológica que defendemos é recente, voltada para a ruptura de paradigmas conservadores presentes na formação e na prática das relações públicas no Brasil, que enfatizam solicitações de grupos privados em oposição aos interesses públicos da esfera pública.

Pela ótica da formação conservadora, os públicos são "criados" a partir das demandas de grupos e setores representados pelo alto poder econômico e da hegemonia político-institucional sustentada pelo capital, com o auxílio das técnicas de relações públicas.

Na atualidade, claros contornos democráticos no Brasil fazem surgir novos públicos, exigindo do profissional de relações públicas nova postura, que rompa com paradigmas tradicionais. Esse processo implica construir novo ethos, alicerçado em patamar teórico e ético-profissional crítico, cabendo aos profissionais da comunicação uma reflexão sobre a ética vigente na sua atividade. Esteves (2007, p. 290) traz a seguinte contribuição:

\footnotetext{
De um ponto de vista estritamente comunicacional, podemos dizer que a ética não tem apenas que ver com a comunicação entendida em termos normativos (a comunicação argumentativa), mas também com a comunicação enquanto processo - a comunicação como realidade dinâmica e contingente que a todo momento põe em jogo o próprio conceito que a pretende definir. Trata-se, pois, de uma ética da discussão (...), uma ética que se preocupa com as normas fundamentais da moral e do direito, cujos conteúdos são objeto do debate do discurso social histórico.
}

Esteves (2007) define a ética da discussão como processual, gerada a partir dos conteúdos morais que advêm do momento histórico e do mundo da vida daqueles que são seus sujeitos, os homens em suas relações sociais cotidianas. Segundo o autor (Esteves, 2007, p. 293), é no cotidiano que "fluem as questões morais concretas". Nesse paradigma, o comunicador passa a perceber a necessidade de sua inserção em um novo projeto ético-profissional. Sensível às discussões da sociedade

1 Graduamo-nos na Universidade Estadual de Londrina em 1986, no curso de Comunicação Social, com habilitação em Relações Públicas, tempo no qual a necessária reconstrução de paradigmas no transcorrer da história das práticas profissionais nos inquietou. 
civil, promove um debate profícuo sobre o entendimento das relações mais próximas e da direção para necessárias rupturas contra a inércia e a favor do protagonismo e da emancipação de sujeitos individuais e coletivos. É uma proposta exigente e atingível, uma vez que sua concretude pode ocorrer na prática profissional cotidiana, local dos diálogos e argumentos colocados na esfera pública. Seu principal compromisso é elucidar, por dentro das relações sociais, o sentido da democracia como sinônimo de soberania popular.

\section{O MUNDO DA VIDA: PAVIMENTO DA ESFERA PÚBLICA}

Na dialética entre Estado e sociedade, Habermas (2013) afirma que ambos devem absorver suas funções políticas, permitindo a criação de uma esfera pública politizada, formada por cidadãos que discutem democraticamente os caminhos da sociedade civil e do Estado com responsabilidades e compromissos dentro dela. 0 autor propõe alterar o ponto de vista sobre o mundo da vida, cuja vitalidade se configura pela ação comunicativa entre seus membros, visando ao entendimento baseado na solidariedade. Afirma que

uma alteração radicalmente democrática do processo de legitimação visa a um novo equilíbrio entre os poderes de integração social, de forma que a força socialmente integradora da solidariedade - a "força produtiva da comunicação" - possa impor-se aos "poderes" dos outros dois recursos de regulação, que são o dinheiro e o poder administrativo, e, com isso, afirmar as exigências do mundo da vida orientadas em termos práticos (Habermas, 2013).

0 agir comunicativo, para Habermas (1989), é ao mesmo tempo o fundamento e a ação geradora da esfera pública, reproduzindo-a e dando-the sentido, na busca da compreensibilidade entre seus atores, ancorado no mundo da vida.

$\mathrm{Na}$ atualidade brasileira, essa esfera pública tem importante papel na democracia, como espaço formador e catalisador da opinião pública. É através da comunicação que ocorrem os debates e encontros de opiniões, dando vitalidade ao espaço público. 0 mundo da vida, que lhe dá existência, tem natureza dialética, reconstruindo-se permanentemente pelas vozes conflitantes dos que ali se apresentam. Conforme Habermas (2003), é lugar de interlocução entre a sociedade civil e demais interesses presentes na esfera pública em busca do entendimento. Nele forças contraditórias atuam, geralmente para desarticular o movimento e a organização da sociedade civil, inviabilizando a legitimidade de processos que se forjam naquela interlocução e a opinião pública dela resultante.

É esta a ação dialética que dá concretude ao mundo da vida. Sua vitalidade deve ser alavancada pelo comunicador, a quem cabe estimular positivas relações para a progressiva democratização da convivência social, cultivando a crítica e a capacidade de formular e avaliar propostas que apontem para uma nova ordem. Portanto, é preciso compreender a esfera pública como

um fenômeno social elementar, do mesmo modo que a ação, o ator, o grupo ou a coletividade; porém, ele não é arrolado entre os conceitos tradicionais elaborados para descrever a ordem social. (...) Do mesmo modo que o mundo da vida tomado globalmente, a esfera pública se reproduz através do agir comunicativo, implicando apenas o domínio de uma linguagem natural; ela está em sintonia com a compreensibilidade geral da prática comunicativa cotidiana (Habermas, 1997, p. 92).

Há que se resgatar a natureza pública das questões públicas e sua distinção dos interesses privados, ainda que imbricados. Os estados democráticos contemporâneos tentam falsear esta distinção ao enfraquecer o caráter público dos sujeitos participantes da esfera pública. No entanto, em virtude de forças contraditórias, nessa esfera é que a democracia se concretiza pelas expressões de opiniões diversas visando ao entendimento e à solidariedade. A comunicação representa uma força mediadora e articuladora entre o mundo da vida e as instâncias decisórias de uma sociedade democrática. 
Costa (1995) analisa a esfera pública sob a influência dos modelos funcionalista e teórico-discursivo. 0 primeiro considera a esfera pública como um mercado de opiniões. Seus atores têm a intenção de formar uma opinião pública capaz de influenciar as instâncias de decisão a respeito dos temas públicos, com base em paradigmas orientados pelos interesses dos formadores de opinião. Nesse contexto, são os grupos com melhor capacidade de articulação e maior poder que definem as temáticas da agenda-setting, enquanto o Estado se vale de ações de relações públicas para manipular a opinião pública. Para Costa (1995, p. 56),

o governo busca assumir o tratamento de problemas cujas soluções encontrem "aceitação mais ampla possível", evitando questões polêmicas. Neste contexto, afirma-se que o Executivo atua tanto como destinatário como quanto coformador da esfera pública. Ele pode, mediante seu trabalho de relações públicas, estimular a discussão daqueles problemas que revelem boas perspectivas de encontrar uma decisão consensual, ou, ao contrário, dificultar a "carreira" de temas que sejam potencialmente conflituosos ou cujo tratamento ameace os interesses estabelecidos. ${ }^{2}$

Entretanto, aparecem nessa esfera atores de protesto (sociedade civil) que, embora disponham de menor poder de organização e influência sobre as bases de decisão, têm na esfera pública a mais importante forma de organização política e de visibilidade.

Na concepção teórico-discursiva de esfera pública, a obtenção de apoio da opinião pública passa por estratégias de manipulação pressupondo uma legitimidade obtida por meio de um autêntico processo de comunicação organizado entre os participantes dessa esfera.

Habermas (apud Costa, 1995) acredita nos entendimentos produzidos na esfera pública pela parcela emancipada que participa do mundo da vida, pois é capaz de concorrer com as demais forças sistêmicas existentes que buscam forjar 0 consenso nessa esfera. Para o autor, a prática da comunicação cotidiana, num modelo democrático de esfera pública, pode influenciar tomadas de decisão entre as suas instâncias deliberativas. Nesse contexto,

Aos atores da sociedade civil é atribuído, portanto, neste construto, um papel duplo, que reflete o caráter bidimensional destes sujeitos. A condensação de "situações-problema" percebida na vida cotidiana corresponde à dimensão defensiva de tais atores. Trata-se aqui da preservação e ampliação da "infraestrutura comunicativa" do mundo da vida e da produção de "esferas públicas alternativas" (Costa, 1995, p. 59).

0 modelo teórico-discursivo, analisado com base numa perspectiva empírica, é exigente quanto à práxis argumentativa e de legitimidade na representação de seus atores. Segundo Costa (1995), tal limitação ocorre porque, muitas vezes, os interesses que permeiam as ações dos representantes da sociedade civil fazem com que eles ajam movidos por paradigmas do modelo funcionalista, que vê, na esfera pública, um mercado de produção de opinião pública. Para que as ações dos representantes da sociedade civil tenham legitimidade, é fundamental que sejam alicerçadas em bases comunicativas, sensíveis aos apelos da opinião pública representada por eles.

Pesquisadores ora defendem a formação de uma esfera pública mundial como base de construção dos pilares de uma democracia no contexto da globalização, o que denominam de democracia cosmopolita, ora acreditam que tal esfera pública global enfraqueceria os vínculos necessários à solidariedade do mundo da vida. Compartilhamos do pressuposto de que esses vínculos fundamentam e fortalecem as relações dos sujeitos que participam da esfera pública. Avritzer e Costa

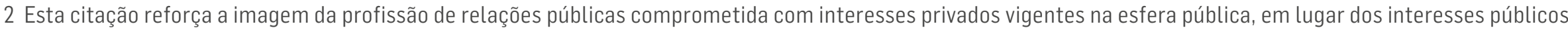
que ontologicamente deveriam representar. 
(2004, p. 715) afirmam que "faltam hoje novas possibilidades de reconstituição dos laços de integração e solidariedade social que, extrapolando as fronteiras nacionais, correspondam à dinâmica econômica transnacional existente". Para se articular necessitam dos vínculos interativos, próprios do mundo da vida.

A comunicação transnacional não conecta as diferentes nações numa só agenda de discussão, mas, a partir das diferentes identidades e culturas de cada nação, são abertos fóruns transnacionais de discussão.

A comunicação pública tem em sua natureza pública essa possibilidade de conexão, pois está em sua gênese 0 acesso e a liberdade de todos os cidadãos ao espaço público. 0 pano de fundo da comunicação pública é a democracia. Só nesse contexto é possível a liberdade de movimentação da sociedade civil no espaço público

\section{COMUNICAÇÃO PÚBLICA E OS ATORES DA ESFERA PÚBLICA}

A comunicação pública, ao atuar como um dos elementos performáticos da vida democrática, traz ao espaço público uma dimensão humanista e democrática, dotada dos princípios de tolerância e de coabitação indicados por Wolton (2006). 0 autor menciona a terceira globalização, não mais política e nem econômica, mas cultural, o que traz à tona a necessidade de se dar atenção aos conceitos da diferença e da tolerância, por extensão. Nela o respeito às diferentes identidades é condição fundamental para o convívio cultural, étnico e social. Segundo Wolton (2006, p. 128), "não existe aldeia global, mas uma tectônica de placas culturais". Trata-se de um espaço público regido pela tensão, que preserva a heterogeneidade, é laico, democrático e dá espaço aos diferentes valores artísticos, culturais, espirituais e religiosos.

A coabitação cultural é o meio de administrar pacificamente a terceira globalização, isto é, o surgimento do triângulo infernal (identidade, cultura, comunicação, nas relações internacionais). (...) Não há cultura global nem mestiçagem ou cosmopolitismo generalizado, há a necessidade de respeitar a diversidade cultural, organizando a coabitação das culturas sobre uma base democrática (Wolton, 2006, p. 233).

A função mediadora da comunicação pública enfatiza a visão comunitária de solidariedade e cidadania. A sociedade civil constrói seu espaço público com argumentos sobre questões de interesse público no mundo da vida. Para esta esfera são encaminhados problemas de associações, organizações, movimentos sociais que emergem das relações estabelecidas no cotidiano, que são discutidos por seus atores buscando formas para superá-los.

Consideramos importante compreender a comunicação pública como um resgate da função social do comunicador na esfera pública democrática, não como uma especialidade, mas como conceito em permanente construção, na dinâmica social. Refere-se a um posicionamento crítico e transformador do comunicador social diante das demandas sociais que se apresentam na atualidade.

A esfera pública é o espaço para onde convergem diferentes experiências cotidianas de vida, para o qual indivíduos levam suas frustrações e desejos em relação aos mais diversos temas. Reconhecem o espaço público como sua esfera de empoderamento, por meio da organização coletiva, que se ancora no mundo da vida via procedimentos comunicativos acessíveis a todos, que vão dos mais simples aos mais complexos. São esses os novos atores da esfera pública das sociedades democráticas, "antenados" nas temáticas públicas atuais, mobilizando-se e reivindicando melhorias. É nesse sentido que o público passa a ser respeitado em sua autonomia, pois 
os papéis de ator, que se multiplicam e se profissionalizam cada vez mais através da complexidade organizacional, e o alcance da mídia têm diferentes chances de influência. Porém, a influência política que os atores obtêm sobre a comunicação pública tem que apoiar-se, em última instância, na ressonância ou, mais precisamente, no assentimento de um público de leigos que possui os mesmos direitos (Habermas, 1997, p. 96).

A mobilização social se concretiza a partir de decisões tomadas no cotidiano pelos públicos participantes da esfera pública, num processo contínuo de troca de informações, de construção coletiva de conhecimento e autoconhecimento. Uma mobilização assim parte de pessoas que vivenciam os mesmos problemas, cujos relacionamentos criam vínculos e interagem pela ação comunicativa.

A comunicação é inerente à natureza do processo de mobilização social. Ela se concretiza quando há o encontro entre o eu e o outro, numa comunhão de ideais. Deve ser não restritiva, pública, ampla, irrestrita e igualitária. A ação comunicativa, pertinente ao mundo da vida, leva à conscientização do sujeito-coletivo-público sobre sua necessidade de organização numa permanente mobilização social, por meio de um projeto coletivo, uma vez que se baseia na vivência e na história do sujeito. Esse novo público que se reúne na esfera pública discute e delibera a respeito de questões de interesse público, visando garantir seus direitos enquanto cidadãos.

Na perspectiva dos novos movimentos sociais (NMSs) que vêm ocupando os espaços públicos em nível mundial, o direito a ter direitos passa a ser uma conquista do cidadão e não mais uma dádiva do Estado, pois se baseia no direito à igualdade e dignidade entre os diferentes povos e nações presentes no contexto da multiculturalidade. O que está presente nestes NMSs é a " cidadania social"3, conforme Santos (1996). Podem ser definidos como ações cívicas, objetivando mobilizar pessoas para se auto-organizarem. As informações são disseminadas por meio das diversas redes sociais, não havendo coordenação porque o movimento é baseado na horizontalidade da comunicação e da organização com iguais chances de participação e voz (Escudero, 2015, p. 62-63).

Toro e Werneck (2007) referem-se à necessidade da existência de um "horizonte ético" que oriente a mobilização, uma vez que se trata de um projeto para o futuro, de uma busca que reflete uma visão utópica da realidade, com a finalidade de sua transformação. Trata-se da construção coletiva de um sonho dos cidadãos, numa perspectiva normativa, pautada no principio ético da criação de uma sociedade mais justa e igualitária, na qual o cidadão participa ativamente tanto da relação vertical, entre ele e o Estado, quanto da relação horizontal, entre os cidadãos na esfera pública. Definimos esse horizonte ético como uma postura ético-política assumida pelo público na esfera pública, ou seja, quanto mais esse público participa do processo decisório sobre questões de interesse público, mais sua opção ética se reflete nas deliberações e decisões tomadas naquela esfera.

No caso brasileiro, o ressurgimento da sociedade civil durante o processo de democratização está associado à emergência de movimentos sociais tais como o sindicalismo, os movimentos de base ligados á igreja católica e o associativismo profissional da classe média. (...) 0 ressurgimento da sociedade civil no Brasil, instituindo novas formas de ação, reivindicando novas práticas políticas por parte da sociedade política, vem questionar a ideia da cultura política predominante de desmobilização e parasitismo. A institucionalização de mecanismos legais e efetivos, enquanto demandas sociais, contribui para a construção da cidadania (Bezzon; Oliveira, 2006, p. 11).

Assim, essa exigência parte de um novo público que se revela pela dinâmica social, processual e contraditória. Público concebido como uma trama que enlaça o possível, no mundo da vida, o utópico e o desejado, a crítica e a autorreflexão, e assim

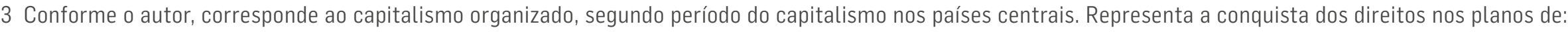
trabalho, segurança social, saúde, educação e habitação. 
tem condições de criar novos valores e tê-los reconhecidos na esfera pública. Esse novo público que se desenha na jovem sociedade democrática brasileira representa o movimento dialético, pois é na contradição, na pluralidade das situações do contexto sócio-histórico que ele se concretiza. Nessa dinâmica, percebemos um novo receptor, que não é mais um sujeito passivo, e sim mais bem articulado e atento às diferentes vozes que ecoam na esfera pública, pela ação comunicativa.

Não se trata de um público "criado" pelo profissional de relações públicas, mas um público que se estabelece a partir da sua prática nos movimentos sociais e da sociedade civil.

Os públicos constituem forças mobilizadoras da sociedade civil no espaço público. São os primeiros protagonistas da modernidade, segundo Esteves (2003).

O novo público do terceiro milênio, que mescla o popular e o elitista, o difuso e o contextualizado, exige mudanças éticas na postura do profissional de comunicação, uma vez que este se acha inserido no ambiente de uma sociedade civil cujas bases democráticas requerem um posicionamento social não excludente. A comunicação pública representa, nesse aspecto, uma proposta que se vale do processo, do movimento social e de seu contexto para vir à tona, emergindo do sujeito e a ele retornando. $A$ comunicação atua na perspectiva possível desses sujeitos, conforme sua capacidade crítica e criadora, aproveitando elementos característicos de cada público. Ela não segue modelos ou rótulos, sendo aprendizagem coletiva sobre as possibilidades de transformação social, oportunizando o que Avritzer e Costa (2004) definem como "alfabetização política".

Nessa perspectiva a comunicação subverte a abordagem técnica e aparelhada comum ao paradigma dominante, privilegiando a interatividade emissor-receptor, pautada em uma vertente humanizada, politizada, onde o receptor não é mais o objeto passivo da comunicação ou sua "massa de manobra". A comunicação

é um processo muito complexo de negociação entre as ideologias e as representações do receptor, que lhe permitem filtrar o que vem do exterior. Sim, o receptor é sempre ativo, esteja ele lendo, escutando, assistindo ou usando o computador. Sim, o receptor é o grande enigma da comunicação, um enigma cujo interesse é crescente com a globalização da informação e da comunicação (Wolton, 2006, p. 33).

A comunicação, quanto mais horizontal, mais inclusiva é dos públicos em seu processo. Os públicos, enquanto sujeitos coletivos, têm uma dimensão ético-política cuja natureza social é coletiva e transformadora, delimitada por um contexto sócio-histórico. Esse contexto é sempre movediço e, portanto, passível de ruptura pela força dos movimentos e das redes sociais, que contraditoriamente vão concretizando diferentes ideias e ações.

0 público faz parte do contexto da esfera pública, age sobre este como ser mobilizador (sujeito coletivo) e, ao mesmo tempo, é objeto deste contexto. Além da força mobilizadora, seu protagonismo está vinculado muito mais a um ideário transformador, a uma vontade política de interferir sobre e nesse contexto, não apenas a uma real capacidade de organização social. Diferentes forças concorrem no cenário da esfera pública e estas nem sempre favorecem ações organizadas e racionais. Apesar desses contextos nem sempre favoráveis, este grupo continua a ser um público, formador de opinião e da sociedade civil, por meio da comunicação pública (Escudero, 2015, p. 46).

\section{O COTIDIANO PROFISSIONAL NO MUNDO DA VIDA: BREVE RELATO}

0 referencial exposto inspirou nossa prática profissional na comunidade do Jardim União da Vitória, bairro da periferia da cidade de Londrina/Paraná. Iniciamos as atividades como professora num projeto de extensão da Universidade Estadual de 
Londrina vinculado ao Projeto de Educação do Assalariado Rural Temporário (Peart) na década de 1990. Atuamos na área da comunicação atendendo ao interesse da comunidade em criar seu próprio veículo de comunicação. ${ }^{4}$

Esse bairro foi a primeira ocupação urbana da cidade de Londrina, ocorrida em agosto de 1985, quando quinze famílias de três favelas decidiram se apropriar do terreno, até então uma fazenda. Atualmente cerca de 16 mil pessoas habitam 0 bairro ${ }^{5}$. Ao longo desses anos, a comunidade, estereotipada pela mídia local como "invasores de terras", "marginalizados", fez dessa dificuldade um mote de luta por seus direitos enquanto cidadãos. Essa luta resultou na consciência diferenciada dos moradores, formando um público disposto a forjar a transformação da sua vida pessoal e familiar e da realidade onde se inseriam.

São esses os atores que conhecemos na dinâmica dos movimentos sociais que construíram a história do Jardim União da Vitória e que, num contexto localizado, representam parte do novo público das sociedades democráticas da modernidade. Esse grupo assume papel fundamental na sociedade quando se organiza em movimentos sociais na esfera pública. É nesse momento que ele deixa de ser plateia manipulada pelos meios de comunicação ou por outros organizadores da agenda de discussões e passa a ser protagonista desse importante cenário democrático que é a esfera pública.

\section{A formação do Conselho de Entidades do Jardim União da Vitória}

Em 1993, no início da organização comunitária democrática, criou-se o conselho de entidades, para fortalecer as lutas em defesa dos direitos dos moradores em diversas áreas de atuação. Ativo até os primeiros anos do segundo milênio, o conselho trouxe importantes benefícios. Participavam os comunitários ${ }^{6}$, suas lideranças e integrantes dos equipamentos públicos atuantes, considerados como intelectuais orgânicos do contexto comunitário. Comprometido com uma prática livre e democrática, sem engessamentos estruturais, o conselho desenvolvia de modo aberto as suas atividades. A cada reunião era escolhida a coordenação, garantindo a alternância de poder, preocupação que hoje faz parte dos novos movimentos sociais. Igualmente, não havia regulamento nem atas para seu registro. Em avaliação posterior, os comunitários perceberam que essa ação livre, importante na época, não preservou a história do movimento social. Atualmente é lembrado por grande parte $^{7}$ dos comunitários como o melhor exemplo de organização popular que já houve na comunidade.

Antes do conselho existia a associação de moradores, que, na avaliação dos comunitários, era conduzida com objetivos político-partidários, não atendendo às demandas locais. Havia na comunidade comissões visando atender às diferentes necessidades da população: comissão da mulher; da saúde; da escola; do trabalho. Já naquele momento o bairro desenhava sua atuação na organização das políticas públicas promulgadas pela Constituição de 1988.

Considerando que o modelo da associação de moradores não representava a comunidade nem promovia a justiça social, os comunitários criaram o conselho de entidades, que contemplaria esses objetivos em sua estrutura, no qual participaram diversos grupos locais atuantes, como os representantes da comissão de rua e da associação de moradores, além da diretora da escola pública da comunidade. Todos teriam assento no conselho, desde que atendessem a demandas coletivas.

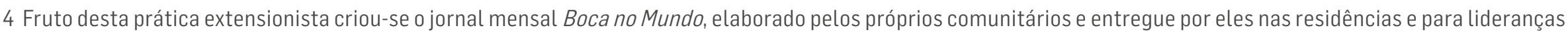
de Londrina. Até hoje é lembrado como importante veículo de comunicação existente no bairro.

5 Dados do IBGE de 2010.

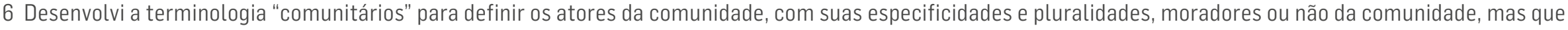

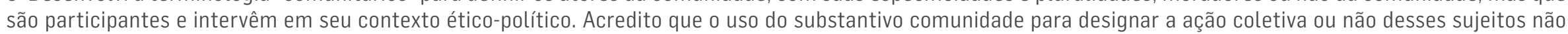

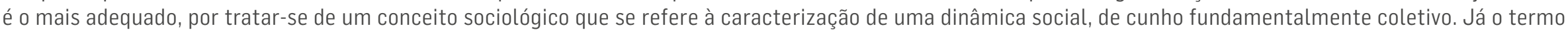

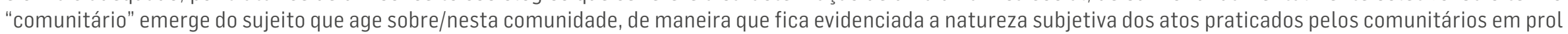
da comunidade e em nome dela.

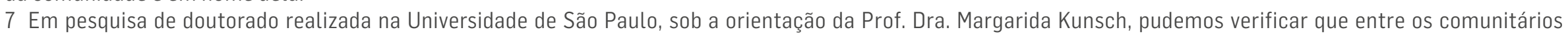

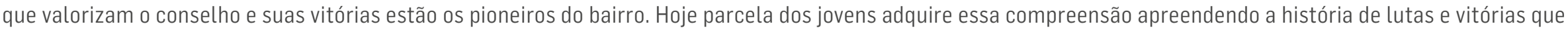
envolve o Jardim. União da Vitória.
} 
As reuniões mensais do conselhoeram conduzidas democraticamente e os temas discutidos e deliberados eram apresentados e definidos por ordem de prioridade. As reuniões apresentavam um bom nível de envolvimento da comunidade. Após os debates, definiam-se comissões para solucionar as reivindicações, num prazo definido pelo conselho.

0 conselho de entidades obteve importantes ganhos para a consolidação de direitos dos cidadãos que ali residiam, tais como:

1) Nome, número nas residências e CEP nas ruas, que antes não existiam. Assim, se já havia um estereótipo por parte da população londrinense quanto ao morador do "União da Vitória", identificado como vândalo, procurar um emprego e falar que morava na rua sem nome e sem número nesse bairro era um verdadeiro ato de heroísmo! Tanto o nome do bairro como o das ruas foi dado pelos seus comunitários: o nome do bairro em razão da força da coletividade que proporcionou a vitória da comunidade; e o nome das ruas em homenagem aos profissionais que ajudaram a construir a comunidade: Rua do Sapateiro; da Cozinheira; do Professor; do Fotógrafo, dentre outros. Essa ação reforçou o espírito de pertença dos moradores e garantiu a elevação da autoestima e da segurança em face de um direito humano fundamental: a moradia.

2) Escola de jovens e adultos. Uma comissão, formada por membros do conselho de entidades, da pró-reitoria de Extensão da UEL e professores de educação, administração e comunicação, implantou o sistema de educação de jovens e adultos (EJA), capacitando um grupo de estudantes a entrar no ensino superior e hoje atuando como profissionais de diferentes áreas.

3) Implantação das políticas públicas municipais: o conselho colaborou na implantação das políticas municipais de assistência social e da mulher como um dos maiores legados políticos desse movimento social. Faziam parte da vivência e cultura locais discussões e deliberações nessas áreas dos direitos sociais. Segundo um dos comunitários, a Secretaria de Assistência Social do Município, à época, fazia assistencialismo, distribuindo cestas básicas às famílias. Inexistia a Lei Maria da Penha, mas o conselho já discutia a questão dos direitos da mulher. Assim, para esse comunitário, o ganho do conselho não foi só de um indivíduo, mas ampliado ao cidadão do município na esfera pública. Houve outros ganhos ligados à infraestrutura: saneamento básico, luz, asfalto, posto de saúde, escolas.

A atuação que temos com a comunidade, no conselho e nas demais ações, cria no profissional a certeza de sua participação como intelectual orgânico, aproximando-nos de outros intelectuais orgânicos, emergidos do local onde habitam e que têm como objetivo a defesa dos interesses coletivos na esfera pública.

\section{Grupo de Jovens: retomando a história e fortalecendo a identidade local}

Na continuidade do nosso trabalho, desenvolvemos uma ação com um grupo de jovens estudantes em uma escola da comunidade o qual faz a montagem de um teatro sobre a história do bairro União da Vitoria, a fim de fortalecer o sentimento de pertença e de identidade local, mediando relações no âmbito municipal. Os frutos desse trabalho já vêm sendo colhidos, com depoimentos dos participantes, relatos que declaram orgulho por morar no bairro, e das pessoas que lutaram por eles, no lugar da vergonha que sentiam inicialmente, até mesmo por não conhecerem a sua história.

\section{CONSIDERAÇÕES FINAIS}

Nossa proposta neste artigo foi discutir a respeito das questões privadas que invadem a esfera pública e que tentam burlar o real propósito desse contexto, que é a discussão de autênticas questões de interesse público. 0 interesse privado 
muitas vezes se transfigura em interesse público, manipulando os atores da esfera pública em torno da discussão de questões de interesse puramente particulares.

Entretanto, a esfera pública tem representado na atualidade o cenário dos novos públicos, que ensejam as transformações sociais, sendo os protagonistas da sociedade civil e dos novos movimentos sociais da atualidade. Esse novo espaço tem um sentido democrático, pois representa um contexto de engajamento, articulação e compartilhamento de ideias e sentidos entre seus atores para deliberar sobre as demandas de interesse público.

Outro aspecto apresentado pelo artigo e que merece ser destacado é o papel da comunicação pública no contexto dessa esfera pública democrática, demarcando espaços de oportunidade para novos atores e novas formas de comunicação, desta vez espontâneas, criativas e formadas a partir das concepções culturais de seus públicos criadores. A comunicação pública é inclusiva, acessível a todos e por isso democrática. Sua dinâmica é sempre coletiva e pautada na defesa de questões de interesse público, possibilitando sua visibilidade e publicização.

Já na perspectiva prática, os comunitários que fazem parte das atividades comunitárias relatadas têm como diferencial seu nível de alfabetização política e de vontade política transformadora de sua realidade. São atores do espaço público, que buscam a consecução de seus direitos, conquistados graças à sua capacidade sempre renovada de organização social. 0 contexto que orienta tais ações é o mundo da vida, situado sócio-historicamente, criador de vínculos fecundos pelos relacionamentos que lhes são próprios e pela solidariedade presente nas relações que se articulam em torno de interesses comuns. Nesse contexto a nossa atuação como relações-públicas oferece possibilidades transformadoras.

Finalizamos esta reflexão almejando que as referências e os relatos aqui expressos possam motivar profissionais da comunicação e de relações públicas para uma visão crítica das relações entre o público e o privado presentes na esfera pública. Esperamos poder continuar contribuindo em defesa da cidadania, em especial daqueles sujeitos subalternizados pelas relações dominantes de poder que, em geral, vêm sendo confirmadas pela mídia.

\section{REFERÊNCIAS}

AVRITZER, Leonardo; COSTA, Sérgio. Teoria crítica, democracia e esfera pública: concepções e usos na América Latina. Dados - Revista de Ciências Sociais, Rio de Janeiro, v. 47, n. 4, p. 703-728, 2004.

BEZZON, Lara Andréa Crivelaro; OLIVEIRA, Maria José da Costa. O papel da comunicação na construção da democracia e da cidadania brasileira: da abertura política à crise do governo Lula. São Leopoldo, RS: Universidade do Vale do Rio dos Sinos, 2006. p. 1-14. Disponível em: <www.unirevista.unisinos.br>. Acesso em: 05 mar. 2011.

COSTA, Sérgio. A democracia e a dinâmica da esfera pública. Lua Nova: Cultura e Política, São Paulo, n. 36, p. 55-65, 1995. Disponível em: <http://www.scielo.br/pdf/ln/n36/a04n36.pdf>. Acesso em: 12 ago. 2012.

ESCUDERO, Regina. Comunicação pública: a voz do cidadão na esfera pública. Construindo um novo paradigma profissional. Curitiba: Appris, 2015.

ESTEVES, João J. Pissarra Nunes. Espaço público e democracia: comunicação, processos de sentido e identidade social. São Leopoldo: Unisinos, 2003. 
A ética da comunicação e os media modernos: legitimidade e poder nas sociedades complexas. 3. ed. Lisboa: Fundação CalousteGulbenkian, 2007.

HABERMAS, Jürgen. Consciência moral e agir comunicativo. Rio de Janeiro: Tempo Brasileiro, 1989.

. 0 papel da sociedade civil e da esfera pública política. In: Direito e democracia: entre factividade e validade. Vol. 2. Rio de Janeiro: Tempo Brasileiro, 1997. p. 57-121.

Mudança estrutural da esfera pública. Rio de Janeiro: Tempo Brasileiro, 2003.

HABERMAS, Jürgen; ESTEVES, João J. Pissarra Nunes. A transformação estrutural da esfera pública: investigações sobre uma categoria da sociedade burguesa. Lisboa: Fundação Calouste Gulbenkian, 2013.

TORO, Jose Bernardo; WERNECK, Nisia Maria Duarte. Mobilização social: um modo de construir a democracia e a participação. Belo Horizonte: Autêntica, 2007.

WOLTON, Dominique. É preciso salvar a comunicação. São Paulo: Summus, 2006.

Texto recebido em 09.04.2017 e aprovado em 22.05.2017. 